\title{
Religious Developments among the Volga Nations as a Model for the Russian Federation
}

\author{
SERGEI FILATOV \& ALEKSANDR SHCHIPKOV
}

Little is known in the world at large about the Finno-Ugrian and Chuvash peoples of the Volga region (Povolzh'ye). The Muslim republics of the Russian Federation Tatarstan, Chechnya, Dagestan and others - are constantly in the news, but the areas at the heart of European Russia - Mordovia, Mari El, Udmurtia and Chuvashia - are known only by name even to Russians and in the West are not heard of at all. They were annexed to Russia in the sixteenth and seventeenth centuries and slowly but surely both Christianised (having previously been pagan) and russified. Occasional national uprisings and independent spiritual and cultural life were quietly but harshly suppressed, and are now remembered by only a few specialists. The turn of this century saw a short period of national development resulting in the appearance of a national intelligentsia and the first fruits of artistic endeavours. Under the Bolsheviks these regions automatically became national autonomous republics and this enabled them to preserve their own languages and created the basis for national life. However, the mortal grip of the Communist Party and its Marxist-Leninist ideology froze this national awakening for another seventy years.

It was only during Gorbachev's period of perestroika that a stormy and painful national awakening could take place, of which religious developments are perhaps the most noteworthy and unusual feature. All these nations were converted to Orthodoxy very late on; paganism, therefore, is better preserved here than anywhere else in Europe, ranging from the survival of pagan attitudes in Christian believers to, albeit more rarely, the worship of pagan gods in forest villages. The current national revival is giving rise to unprecedented possibilities for religious creativity. The search for a national identity means that the leaders of these nations view anything to do with Russian Orthodoxy as 'imperialist', 'occupational' and 'antinational'; wherever possible they are choosing faiths which they can construct along the lines of their local heritage. Some have considered creating a national Orthodox church; some have turned to other Christian denominations, Islam, even Judaism and Zoroastrianism. Yet the most powerful current is the attempt to revive paganism. In the Volga republics, 'religious creativity' has become the concern almost exclusively of the creative intelligentsia - writers, artists, theatre producers, university professors. They are especially concerned about the preservation of national languages, culture and traditions. This social basis of the religious movements gives them their own 'specific character'. The intelligentsia has coloured the religious life of the Volga region with aestheticism, spontaneity and a pretentious 'artistic' style. 
The political processes in each of the Volga republics are tied up in various ways with the religious movements. Nationalistic movements normally have their own clearly defined character. The Russian communities have to choose how to respond, and may turn now to the Moscow Patriarchate, now to the communists. The internationally and ideologically minded nomenklatura are faced with a similar choice; sometimes they clutch at communist ideologies and at other times either imitate the rhetoric of Yel'tsin's 'democrats' or play around with nationalism.

Despite its unique features the religious situation as it is developing among the non-Muslim peoples of the Volga region is in certain respects a clear, albeit often grotesque, reflection of the situation which is developing throughout the rest of Russia. For the majority of people it is characterised by a break with traditional forms of religious life, little knowledge of the essence of religious faith and an amorphous, eclectic religious worldview. It is not, therefore, only the Volga peoples who are open to the preaching of new beliefs - the Russians also, although to a lesser extent, share their susceptibility. For the nationalists of the Volga region Russian Orthodoxy is the 'religion of occupation', while in the eyes of some sections of the Russian population the Moscow Patriarchate is seen to have compromised with the Bolsheviks and so for them 'any faith is better than Orthodoxy'.

The return to religion is not the result of preaching but a natural consequence of the development of secular ideology and culture. The mass media and cultural figures usually play a no less important role than the clergy in the religious revival. This tendency, general throughout Russia, is just rather more obvious in the Volga region, where artists, writers and theatre producers have become the apostles of new religions. The non-Muslim republics of the Volga region are an experimental area where the way religious movements might develop throughout the rest of Russia can be seen in sharp relief.

In late 1993 we travelled to Mordovia, Mari El and Chuvashia, had long conversations and conducted interviews with representatives of the local intelligentsia and leaders of the nationalist parties and religious movements and examined the documents and periodicals of the national movements. Here we present the results of our analysis.

\section{Mordovia}

The indigenous population of Mordovia came into collision with Russian expansionism earlier than did the other Volga nations. The assimilation and Christianisation of the Mordovian tribes began as far back as the pre-Mongol era. The Moscow government pursued this policy systematically and consistently from the seventeenth century onwards. Russians were settled among the Mordovians, baptising them into the Orthodox Church by force. By the end of the nineteenth century every Mordovian sacred grove had been cut down and sacred glades and cemeteries had been ploughed up. However, prayers to pagan gods and the spirits of ancestors were partially preserved in the national culture, as were songs and tales of ancient mythology. The most recaltricant and freedom-loving adherents of their ancestral faith ran away from Russian control to the Urals, establishing Mordovian villages in which today paganism is best preserved. Mordovians still remember the religious movement of the early nineteenth century started by a Mordovian peasant, Kuz'ma Alekseyev, who announced that 'Jesus Christ is not God, but rather an official who has been deposed.' Kuz'ma prophesied that Christianity would die and that the Mordovian faith would prevail throughout the whole world. All nations would wear Mordovian national dress and become like Mordovians. Prayers should be said facing west 
rather than east because 'salvation and freedom' were to come from the west. Kuz'ma Alekseyev's movement gained support throughout the Mordovian settlements and was even joined by some Russians. In 1810 this movement, said to have been founded by 'the Mordovian god Kuz'ka', was suppressed by the tsarist government, but the memory of it is still alive among Mordovians.

Only at the turn of this century did the Holy Synod make its first attempts at civilised missionary work. There were educational initiatives and I. Barsov started translating the Bible and liturgical books; but the revolution interrupted this activity at its very beginning.

The Bolsheviks created the first Mordovian state: the Mordovian ASSR. Mordovians made up only a third of the population of the new republic, while twothirds of Mordovians lived in neighbouring Russian oblasts (primarily Nizhny Novgorod and Penza). The creation of a Mordovian state saved the Mordovians from complete assimilation into Russia and gave rise to a national intelligentsia. In comparison with other autonomous republics, however, the russification policy in Mordovia was quite blatant. By the 1980 s the very existence of the national languages had become problematic. The situation was made worse by the fact that there is no such thing as a 'Mordovian nation'. The concept actually includes two peoples, the Moksha and the Erzya, who are distinct culturally and linguistically. It is not just the 'Mordovians' and the Russians who have been in constant conflict, then, but also the Moksha and Erzya. The religious policy of the communist regime in Mordovia was also extremely harsh even by Soviet standards. Until the 1990 s there were only ten Orthodox parishes, mostly in villages; they did not have their own bishop and were under the jurisdiction of the neighbouring Penza diocese. The harsh policies of the local authorities prevented any flowering of independent national religious life or any noticeable activity by Baptists or other Protestants or sectarians. The programme to 'defeat religion' was a rare success in Mordovia. It is hardly surprising that in every free election in Mordovia since 1985 the communists have received more votes than almost anywhere else; the republic is even known as 'the communist reservation'.

The first to respond to their improved situation were the Orthodox. In 1990 the first Mordovian diocese was created. It is headed by Bishop Varsonofi (Sudakov), a perceptive and energetic man who is better disposed towards the Moksha and Erzya than they think, but is still a Russian sent by the Synod. In the first three years of his incumbency the number of parishes in his jurisdiction tripled to 115 . The number of believers did not grow significantly, however, as most Russians have lost their links with the Church and for Mordovians Orthodoxy remains a foreign religion since services are conducted in Old Church Slavonic. Citing the blessing of the patriarch, Bishop Varsonofi is not opposed to translating services into the vernacular, but nothing is really being done about it. A commission to translate the Bible and liturgical books has been officially created, consisting of an Erzya priest, a Moksha priest and two linguists from the local institute of languages and literature. Their resources are clearly inadequate as the linguists have no theological training and the priests are not linguists. The group has at its disposal only a few translations done at the end of the nineteenth century by Mordovian educators, and a Swedish translation of the Bible for children. The work is further complicated by the existence of two local languages and a lack of funds.

The diocese is poor. The communist authorities in Mordovia have, if not a hostile, then an indifferent attitude towards religion in general and Orthodoxy in particular. Unlike in most other autonomous republics and regions, the Russian Orthodox Church in Mordovia does not receive a subsidy. Village clergy, whose salary at the 
end of 1993 was just 15000 roubles, need to keep livestock and a kitchen garden. The majority of priests have no higher education. They are not up to bringing about the rebirth of Orthodoxy even among those Russians who have forgotten what the church is, not to mention the Mordovians. One of the Mordovian clergy, Fr Vadim Zakharkin, works zealously: he is vociferous in the cause of services in the Mordovian languages and against western missionaries, paganism and the communists. However, his is a lone voice. It is obvious that despite numerical superiority and despite the zeal of the bishop in giving his blessing to the translations, ordaining Mordovians, producing a regular diocesan magazine and himself teaching catechism courses, Orthodoxy is not in best shape in the face of the new national revival.

The national revival in Mordovia had a difficult start. The indigenous nations of the republic were in a minority and the press, which was very influential, took a repressive communist line. The Russian Democrats, headed for a short while by the first president of Mordovia, V. Guslyannikov, and the communists were hostile towards the 'Mordovian nationalists'. No national parties with a mass following have so far been formed. At the start of perestroika the Mordovian national intelligentsia waged a vigorous and in many respects successful campaign which from the very first was hostile to Orthodoxy, 'the religion of occupation', 'the russifying ideological force'. 'If only we had a Mordovian bishop and a liturgy in Mordovian!', one Mordovian whispered to us. 'But would the Russian church ever allow it?'

The cultural revival means for Mordovians in the first instance the revival of folklore, crafts and costume, namely all that is indissolubly connected with paganism. The Orthodox priests' opinion is clear: 'The Saransk Ministry of Culture is creating a pagan faith.' This view is not unfounded. These were the circles that produced the first neopagans headed by the poetess Raisa Kemaikina. Kemaikina was the leader of a group of the Saransk intelligentsia whose aim was the complete reconstruction of a pagan worldview and religious services based on a reworking of ethnographical, folkloric and linguistic material. Before long a separatist Erzya party appeared: 'Erzyan Master' is still very small, but all its active members are pagans and they have declared that the spread of paganism is one of their political aims. In a 1992 interview with the Chuvash newspaper Atlant Kemaikina was asked 'What is your attitude towards Christianity?' She replied:

I am strongly opposed to it. In its role as the official state religion of Russia Christianity suffocated the religions of other nations, transforming them into involuntary spiritual slaves.

Russia has long been called 'the prison of the nations'. I think this is too mild. It is worse than a prison. Sooner or later people get out of prison and become masters of their own fate again. A prisoner is someone who has lost his or her freedom temporarily. But a slave is not a prisoner - he doesn't even desire freedom. Over the course of many centuries Christianity has bred our peoples into slaves, depriving them of freedom of thought and reducing them to the level of submissive cattle.

In the Erzya religion the relationship between God and human beings is different from that in Christianity. It is deeper, more humane, more beautiful ... In our religion a person's worth is not killed or suppressed, but extolled. You never hear things like 'you are God's slave', or 'turn the other cheek', or 'if someone takes your coat give them your shirt as well', or 'bless your enemy'. 
In 1992, in one of the most patriarchal and traditional villages of Mordovia, Kemaikina (pagan name Kemalya) organised the first pagan prayer session for decades or even centuries, sponsored by some Mordovian businessmen. All the neighbouring villages enthusiastically learned long-forgotten pagan prayers and Kemaikina was proclaimed the first priestess of the Erzya people. Television reports on this and subsequent prayer sessions caused a sensation throughout the republic. 'The pagan question' is being discussed everywhere from the remotest villages to university auditoria.

Christianity is rooted too deeply in the Mordovian national consciousness, however, for the agents of the religious revival to break with it without compromise. 'Before my mother went to sleep each night,' Kemaikina remembers, 'she repeated in higgledy-piggledy fashion both psalms in Slavonic and ancient Erzya prayers to our pagan god Ineshkipaz.' A synthesis of Mordovian national spiritual culture and Christianity is what actually constitutes Mordovian national consciousness. It is not surprising that within the Mordovian national movement another movement has arisen concerned with the ideological formation and organisation of another religious worldview which has arisen spontaneously among the people and which is linked with Finnish Lutheranism. In the past few years the mutual interests of Finns and Mordovians, who are related peoples, has led to the setting up of a wide variety of links and has already led to the appearance of Mordovian Lutheranism.

The rise of the Mordovian Lutheran Church is one of the most striking phenomena of religious life in the Volga region. It is also typical: because Mordovian Lutheranism is the fruit of a spiritual search on the part of individuals in the humanitarian and artistic elite, in this case the artist Andrei Aleshkin.

This talented young man from a Mordovian village gained a place at the Leningrad Academy of Art. Through his extremely intellectualised creations he attempts to give expression to his philosophical and religious search. In Leningrad and later in Saransk Aleshkin has created series of pictures and prints which are reflections in colours and images on Finno-Ugrian mythology and on his search for Christianity - a search which he is conducting within the Russian Orthodox tradition. Aleshkin became a member of the elite St Petersburg creative intelligentsia. Academician D. Likhachev and others are following with great interest this unusual young artist and thinker in his attempt to unite the world of Orthodoxy and Russian classical culture in which they were born and brought up with unknown elements of Mordovian myth, epic and folklore. Of all Aleshkin's St Petersburg acquaintances, the most significant was the local Finnish-Ingermanlander Arvo Survo, one of the small population of Finnish-Ingermanlanders in the Leningrad oblast, a group which has led the religious revival of its nation. During the years of perestroika the Ingermanland Lutheran Church, which had been completely destroyed by the Bolsheviks, was revived with the help of Lutherans from Finland. Arvo Survo is striving to create not just another diocese under the Helsinki jurisdiction but an actual Ingermanland national church with its own culture and rituals, and he has not been afraid of taking issue with his Finnish sponsors in so doing.

Aleshkin returned to Saransk to universal recognition of his talent. He was elected as the first non-nomenklatura president of the Artists' Union of Mordovia and one of the leaders of the Society for the Study of Finno-Ugrian Culture. These professional achievements have not distracted him, however, from his more lofty aim of the spiritual regeneration of the Mordovian nation. His contacts with the Russian Orthodox Church have convinced him that this church will never renounce the policy of russification, that church services will never be held in the Mordovian language and that 
the interests of Mordovian national culture will never be taken into account.

Aleshkin has convinced several members of the Saransk intelligentsia - university tutors, folklorists and artists keen to bring about a national revival - that the future of Christianity in Mordovia lies in the acceptance of Lutheranism. In 1991 the first community of the 'Dr Martin Luther Mordovian Christian Church' was formed. The authorities gave it a piece of land in the town centre to build a church. Arvo Survo took the first services there and Finnish Lutherans promised material aid. Andrei Aleshkin's brother Aleksei became the new church's first priest. However, the church came up against difficulties as soon as it was registered. The Orthodox clergy unleashed a campaign to discredit the new Lutherans, accusing them of being 'Catholics' and 'Jesuits' (for local Orthodox clergy these are the most serious insults) and claiming that 'homosexuality is an obligatory element in Lutheran church services'. The Orthodox diocese has demanded that the authorities revoke their decision to donate the piece of land for the church to be built.

What Aleshkin did not expect was conflict with his Finnish sponsors, who became dissatisfied with the 'wilfulness' of their wards. The Aleshkins wanted to create a church which would reflect the spiritual and cultural characteristics of the Mordovian nation but the Finns objected and ceased to send aid. One group of parishioners who were not inclined to question the Finnish leaders have broken with the Aleshkins and set up a community under the jurisdiction of Helsinki.

A conflict of this kind was only to be expected. The Finnish missionaries represent today's typical liberal secularised Western European Lutheranism with its formal attitude towards the sacraments, theological liberalism, women priests and support for sexual minorities. In Russia as a whole, and in Mordovia in particular, there is a potential basis which is larger than that in the West for a traditional Lutheranism strongly influenced by Orthodoxy. Mordovian Lutherans not only do not recognise women priests, but have an attitude which is more Orthodox than Lutheran towards all the sacraments, especially the Eucharist. In some Finnish Lutheran parishes the rim of the chalice is wiped with an antiseptic cloth after each communicant has used it, for hygienic reasons, and it is acceptable simply to clean the napkin if crumbs from the elements fall on it; but in more conservative parishes this would be seen as blasphemy and a lack of faith.

Because of this ritual traditionalism, which is derived from the Orthodox environment, the Moksha-Erzya church has decided not to include the word 'Lutheran' in its title. While remaining faithful to the doctrines of Dr Martin Luther its members are trying to distance themselves from the secularising influences which predominate in Finnish Lutheranism. Lutheranism is now spreading in Russia among Germans, Ingermanlanders, Mordovians and even Russians. The conservative version of Lutheranism predominates. We should not rule out the possibility that Russia will become a stronghold of Lutheran conservatism in Europe.

Despite these various problems, the affairs of the Lutheran Church are developing satisfactorily. By early 1994 ten students were taking a course of pastoral studies organised by the Ingermanlander Church in St Petersburg. A Mordovian version of Lutheran worship is being developed: traditional Mordovian spiritual songs are sung in the services and the vestments of the clergy incorporate elements of Mordovian national costume and Orthodox vestments. The question of icon veneration is under discussion and a Swedish institute is working with philologists and writers from Saransk to produce a high-quality translation of the Bible into the Mordovian languages.

The small Lutheran communities which have not had significant support from Finland and have not therefore been able to build their own churches have been 
meeting in private flats; but they have been evangelising enthusiastically and effectively. All the members of the semi-professional folk ensemble 'Taroma', including its leader V. Romashkin, have become converts to Lutheranism. The folk ensemble is a much more important cultural phenomenon in Mordovia than in, say, Russia or Italy. The country's literature, art and music have never been particularly rich and hence folklore is the basis of Mordovian culture. This particular folk ensemble travels throughout the republic with Aleksei Aleshkin, combining acts of worship with the performance of spiritual songs. This troupe of missionaries never make a big thing of their Lutheranism. When they arrive at a village they say 'We're the first to bring you "Mordovian Christianity".' The result is that these peasants, who have a poor knowledge of the Russian language, greet the missionaries with joy and gratitude because of the chance they give them to hear the word of God in their own language.

This community of the 'Dr Martin Luther Mordovian Christian Church' still faces many obstacles, but they are already a phenomenon in the spiritual life of Mordovia. Once such phenomena have arisen, there is a logic to their development which makes them hard to interrupt.

\section{Chuvashia}

Some of the nations in the Volga region - the Tatars and the Bashkirs - are Muslims and Turks; others - the Mordovians, the Mari and the Udmurts - are to a greater or lesser extent Christianised pagans and Finno-Ugrians. One other nation living in this region, however, is both culturally and religiously unique: the Chuvash. The Chuvash are Turks but they have never been Muslims. They are the descendants of the indigenous population of the ancient kingdom of the Bulgars which flourished on the banks of the Volga until 1236 when it was conquered by the Mongol Tatars. Most of these ancient Bulgars - the ancestors of the modern Tatars - mixed with the Mongol Tatars and adopted Islam. Later they founded their own state, the Khanate of Kazan'. The ancestors of the Chuvash, however, remained pagans and gradually formed a separate nation. It was only in the middle of the fourteenth century that, together with the Tatars, they were annexed to Russia.

Despite all attempts by the tsarist government and the Russian Orthodox Church, Chuvash paganism was never completely eradicated. Right up until the mid-nineteenth century Christianisation proceeded by the use of exclusively repressive methods, and Russian immigrants were settled among the Chuvash people. The success of this policy was very limited. It was not until the beginning of the nineteenth century that paganism began to decline on a large scale as Chuvash literature developed and the Bible and other theological texts were translated into the Chuvash language. The main credit for this is due to the Chuvash spiritual teacher Ivan Yakovlev, who, many Chuvash nationalists are now insisting, should be canonised. Orthodoxy was endowed with Chuvash national characteristics, and this process went a good deal further in Chuvashia than in the other Volga republics. In the majority of Chuvash parishes Sunday services were celebrated in the national language even before the revolution and most of the priests were Chuvash. Since then Orthodoxy has become their own native religion for a great many Chuvash people and they have been willing to make sacrifices to defend it. After the revolution the Chuvash nature of the church was preserved. During the period of Soviet rule many courageous believers suffered persecution and Chuvash catacomb communities were formed. It is not by chance that one of the catacomb hierarchies is today headed by the Chuvash Bishop Guri (Pavlov). 
After the revolution Chuvashia became an autonomous republic. Half the Chuvash population and even the main cultural and religious centre of the nation, Simbirsk (Ul'yanovsk), were located outside the republic's boundaries. However, in contrast to Mordovia, Mari El, Udmurtia and Bashkiria, the indigenous people made up the vast majority of the republic's population. Russians constitute the majority only in Cheboksary and in the far south of the republic, in the region around the town of Alatir'. Ideological and political repression was not as successful in Chuvashia as in the Finno-Ugrian republics.

In 1991 the communists lost power under pressure from the nationalists and democrats and their supporters among the economic nomeklatura. From that time the political struggle in the republic has pitted the nationalists against various democratic factions: the communists have given up hope of political power. From the very beginning the religious factor has been of the utmost importance not only in the process of intellectual development but also in the political struggle. During the years of stagnation the Orthodox diocese in Chuvashia had been fortunate. Documents from the Council for Religious Affairs released under glasnost' reveal that the present leader Archbishop Varnava and his predecessor Archbishop Veniamin were in the communists' bad books because of their independence and honesty and their constant refusal to follow the orders of the authorities.

With the onset of perestroika Varnava felt that his time had come. When the communists were overthrown in Chuvashia in 1991 the new people filling the corridors of power asked local priests to bless their offices. Varnava, a consistent anticommunist and a supporter of Yel'tsin, personally baptised and married many of the leaders of the republic and their children. The authority he had acquired during the years of stagnation, reinforced by the popularity of religion among the people, meant that he was able to have an effective influence on the activities of the ruling elite and the national will. In the presidential elections of 1991 Atner Khuzangai, the leader of the national-democratic party the Chuvash National Congress (ChNK), won the first round with 47 per cent of the votes. At that time the ChNK was in favour of creating an independent Chuvash Orthodox Church. Varnava, however, was not in favour and suggested to the Supreme Soviet of the republic that Chuvashia introduce presidential rule, but impose a provisional moratorium on presidential elections to give the nation time to reflect on who would be a worthy candidate. His suggestions was a factor in the postponement of the presidential elections.

Among the political leaders who are believers Varnava has lent his constant support to the chairman of the Council of Ministers, Valerian Viktorov. In 1992 Viktorov had his wife and his daughter personally baptised by Varnava, and then had a church wedding. The 'Orthodox factor' stood Viktorov in good stead in the presidential elections of 1993.

The greater support for Yel'tsin and the weakness of the communists in Chuvashia as compared to the neighbouring republics are to a large extent the result of Varnava's influence, despite the fact that nearly every political group in Chuvashia solicits his support. However, if any party's programme makes so much as a faint allusion to republican separatism or to communism it comes in for episcopal ostracism. For all this, Varnava was not successful in the presidential elections of 1993 when, despite his support of Viktorov, the candidate representing Travkin's DPR, Nikolai Fedorov (who had resigned from the post of Minister of Justice under Gaidar in protest against right-wing nihilism) won a small majority over the Yel'tsinist Viktorov. Khuzangai suffered a shattering defeat ( 7 per cent of the votes). However, Varnarva quickly established excellent relations with the new president 
Fedorov, a believer who regularly attends church with his family. Fedorov included Varnava in a commission drawing up a new constitution for Chuvashia. Material aid to the diocese increased under Fedorov.

The Moscow Patriarchate's style of leadership has, however, left its distinctive mark on the activities of the bishop of Cheboksary. Varnava forbids the Chuvash clergy to cooperate in any way with the communists or the Chuvash nationalists and he is trying to get the Chuvash parliament to pass legislation heavily restricting the activity of western missionaries. This legislation will also be used to restrict 'New Age' sects, including those originating in Russia, such as the 'White Brotherhood'. Varnava is also working for the speedy transfer of all church buildings in the republic to the diocese and significant financial help from the republican, city and regional authorities to restore them. As a medieval-style 'prince of the church' he puts a stop to any free thought or disobedience within the diocese. With the help of the secular authorities, who both fear and respect him, he is fighting to establish the spiritual monopoly of Orthodoxy in Chuvashia.

Varnava has tackled the 'national question' in the church in a similar way. His approach has been good-natured and paternalistic. He takes a logical attitude to the level of 'Chuvashisation' which the church had reached before his time. He does not know the Chuvash language but he has learnt the words of various prayers said during Chuvash services and has given his blessing to the work of a biblical commission in the diocese translating liturgical texts into the Chuvash language. We should also note that of the 150 priests serving in this diocese only 18 are Russian. The rest are Chuvash and, as services in Chuvash on Sundays and feast days indicate, the Russian Orthodox Church is fully accepted by a significant proportion of the indigenous population as a part of Chuvash life. The head of the biblical commission, the Chuvash priest Il'ya Karlinov, enjoys great popularity in the republic and fully supports Varnava's policies. Because of all this the small group of Russian nationalists in Cheboksary are under the impression that the bishop is suppressing the Russians in the church and they have even complained about this in writing to the patriarch.

Alongside the growth in the influence and authority of Orthodoxy and its leader, however, another movement is developing steadily in Chuvashia - a movement with which Varnava is in principle unable to come to terms. The overthrow of communism brought freedom not only to the Russian Orthodox Church but also to the Chuvash national movement. After centuries of suppression, first by tsarist governments and then by the communists, it has awoken noisily, revealing the stormy Chuvash National Congress Turkish temperament of the Chuvash people. As early as the end of the 1980s the Chuvash National Congress (ChNK) was formed as a political party, and the leading figures in the national intelligentsia soon rallied to its support. The professor and philologist Atner Khuzangai, the son of a well-known Chuvash writer, became its leader. The ChNK supports Chuvash autonomy, democratic and market reforms, the 'Chuvashisation' of all spheres of community life and the creation of a federation of all the Volga republics.

To begin with, the religious question was not of great significance. Khuzangai himself is a practising Zen Buddhist. He presented a general democratic programme advocating freedom of conscience and the equality of all religions before the law. When the nationalist movement began the nationalists tried to persuade Varnava to lend them his support - most of them were Orthodox after all. The bishop's very negative attitude towards the ChNK and its leaders in the 1991 elections hastened an inevitable parting of the ways. From that time the idea of an independent (or autonomous) Chuvash Orthodox Church headed by a Chuvash patriarch gained cur- 
rency among the nationalists and the Chuvash clergy. The first heads of the biblical commission in the diocese, writer Mikhail Yukhma and the priest of the Church of Christ's Nativity in the village of Yangil'dino, Ioann Ivanchin, complained repeatedly in writing about Varnava to Aleksi II, accusing him of 'Chuvashophobia' and of not being willing either to promote the use of the Chuvash language in church services or to learn it himself. As a result the bishop fired them from the biblical commission, entrusting it instead to Fr Il'ya Karlinov, an opponent of an independent Chuvash church. Varnava accused Yukhma and Ivanchin of being nationalists and of trying to introduce pagan elements into Orthodoxy. They then accused the bishop of Russian chauvinism.

It was from this point onwards that the nationalist movement began to separate itself from Orthodoxy. Yukhma made contact with the Tatar nationalists and created a tiny socio-political organisation, the Chuvash Socio-Cultural Centre (ChOKTs), which proclaimed Islam to be the Chuvash path to salvation. However, the ChOKTs, Islam and the pro-Tatar movement do not enjoy any real popularity within the republic. The main developments in the religious quest of the national elite are taking place within the ChNK, which quickly became disappointed with Orthodoxy. Like many European nations at the dawn of their history, the Chuvash intelligentsia is choosing its own faith. At meetings of the ChNK animated discussions take place on the merits and drawbacks of Islam, the Baptist faith, Catholicism, Lutheranism and paganism. Some have even put forward Judaism and Zoroastrianism. Several members who are linked with the ChOKTs have chosen to follow Islam. Others have become Baptists. The Catholic and Lutheran Churches are not represented in Chuvashia, so they have not presented a real alternative. The earliest and most natural choice for the nationalists has turned out to be paganism. The majority of Chuvash were pagans 150 years ago, and even today in villages situated deep in the country there live 'pure' unbaptised hereditary pagans who observe some of the rituals of the faith of their ancestors. A charismatic pagan leader has even appeared: a producer at the national theatre, Iosif Dmitriyev, who has given up his job and with all the ardour of his Eastern character has embraced the task of the 'revival' of Chuvash paganism - or rather, its modernised reconstruction. It is Dmitriyev's view that 'there is no need to hurry the revival of the ancient Chuvash faith. A canon must first be established, a set of beliefs, dogmas and rites which can then be put before the nation. After that a disciplined church organisation similar to that of the Roman Catholic Church must be created.'

Although the faith designed by Dmitriyev and his companions-in-arms is monotheistic it includes concepts similar to the Christian Trinity, in that it has the god Tura, the mother-god Asma and the bread-god (the god-son Christ is one of the human incarnations of the bread-god). Tura - the creator-god - is said to be the same in all religions, although different nations attribute different prophets and forms of worship to him; the Chuvash way is held to be the most authentic. This god comes in about 300 forms and incarnations, mostly of an animal nature, so that in some senses there are many gods, and in other senses only one. The ancient Chuvash faith has much in common with Zoroastrianism: Tura is associated with light, fire, the sun and shining heavenly bodies in general. Tura is constantly creating the world; he is the 'the creator, the almighty and the observer'. Just as Tura is engaged in constant creation, so religious consciousness, dogmas and the understanding of truth are constantly developing. Ancient rites of worship therefore have to be preserved until the end of time. The ancient Chuvash faith consists of two mutually complementary levels. The upper level is the worship of Tura, who lifts man above the natural world and who repre- 
sents responsibility, energy and creativity; the lower level is the worship of Asma, which is worship of nature, the world and the world below. In Asma's religion evil does not exist; everything is good. It includes the worship of ancestors and natural spirits.

The year 1992 was an epoch-making one for Chuvash paganism. Iosif Dmitriyev took part in a series of television debates on the theme 'Whose God is best?' along with the most authoritative Orthodox Chuvash priest Fr Il'ya Karlinov, and in the opinion of the nationalists emerged the winner. After this Archbishop Varnava began to take the pagan threat seriously but the only action he took was a series of administrative measures - refusing to let them hire premises, for example. As a result at the end of 1993 Atner Khuzangai was having to tell us 'I am the only ChNK activist who is not a pagan.'

The ChNK received 7 per cent of the votes in the 1993 elections. It may not seem much but they have the support of the flower of the Chuvash intelligentsia. The Chuvash nationalist movement is now mainly pagan.

\section{Mari El}

It is a sensational thing that living paganism is to be found among the European nations of the Volga region described in this article; but what is even more sensational is that among these nations there is one that consists chiefly of pagans: the Mari. Strictly speaking the Mari - the Cheremis as they used to be called - are two very closely related Finno-Ugrian nations separated not so much by language and culture as by their religious identity. A small number of mountain-dwelling Mari live in the region of the town of Koz'modem'yansk. Long ago they firmly adopted the Christian faith and ceased to be pagan, and if today they are not practising Orthodox believers they are certainly bearers of Christian culture. All the rest of the country is inhabited by the plain-dwelling Mari, however, and it is this group which we will be discussing here. They are pagans. According to a recent survey conducted by Mari sociologists, 5 to 7 per cent of the inhabitants of Mari El are 'pure' pagans, 60 per cent are of dual faith (a self-designation describing those who both visit sacred groves and attend church, believing that in these different ways they are worshipping the same God) and only 30 per cent are Orthodox believers, mostly Russians. Two hundred thousand Mari live in the diaspora, the descendants of fugitives from Christianisation, in Bashkiria, Tatarstan and the Urals. Up to 90 per cent of these are 'pure' pagans.

Pagan creeds are being reborn in Mari El in a process of 'confluence'. On the one hand, practically every village has a kart (a pagan priest), who is a figure of authority and who preserves pagan traditions from generation to generation. On the other hand, members of the Mari intelligenstia are moving towards paganism, seeking in it a force to defend the nation against russification. At the end of the $1980 \mathrm{~s}$ cultural, social and political organisations with a pagan ideology arose, and in the 1990s they took concrete shape in the form of the political organisation Kugeze Mlade (Earth of the Ancestors), the cultural union Mari Ushem (Mari Union) and the youth movement U Vi (New Force). The leaders, motivators and rank and file members of these organisations have been recruited from the artistic intelligentsia and include writers, artists, leading journalists, folklorists, university lecturers and professors of Mari language and literature.

Through the efforts of these organisations, the only significant pagan religious organisation in Russia, Oshmari-Chimari (meaning White Mari-Pure Mari), was reg- 
istered at the Russian Ministry of Justice in 1991. Mari writer and elder of the Mari writers' organisation Aleksandr Mikhailovich Yuzykain was elected high priest (tun' onayen'). Oshmari-Chimari has only a few founder members, but it represents and speaks on behalf of all non-organised Mari paganism.

Traditional unmodernised patriarchal paganism has been well preserved in Mari El and has a long history. Under the leadership of Prince Boltush the plain-dwelling Mari fought on the side of the Tatars against Ivan the Terrible and were still offering resistance 50 years after the capture of Kazan'. Ever since then the plain-dwelling Mari have related with pride how they fought for national and religious freedom and they scorn the mountain-dwelling Mari who "fought Kazan"' on the side of Ivan the Terrible. Incredible as it may sound, events which took place in the sixteenth century still have political resonance for the Mari even today. For many the capture of Kazan' is more real than the Revolution or the Great Patriotic War. To run ahead, we should note that the president of Mari El, Vladislav Zotin, is one of the mountaindwelling Mari.

National prayer meetings involving all the pagan priests and tens of thousands of pilgrims continued until 1887, when the authorities banned mass manifestations of paganism. These meetings used to take place at the grave of the legendary eleventhcentury prince Chimbulat, who is revered as heroic defender of the nation of epic stature. By the sixteenth century Chimbulat had been deified in the national consciousness and mass pilgrimages were being made to his grave. In 1830 the grave was blown up, but prayer meetings continued for some time at other sites. In banning these meetings the government struck a serious blow at Mari paganism inasmuch as the latter was held together not by hierarchical structures but by a strictly established cycle of public prayers organised at different levels - the family, the clan, the village, the region. The various kinds of prayer had their own timetables and their own particular significance. The national prayer meetings which took place about once every ten years reinforced a general sense of belonging to one nation. Every generation went through this religious experience, which took on a national and political significance.

Mari paganism was fully functional right up to the October Revolution. Most villages still had their pagan priests, and sacred groves were not cut down as they were in Mordovia and to some extent in Udmurtia and Chuvashia. Hereditary unbaptised pagans ('pure Mari') considered themselves upper class, so to speak, and would not marry anyone who had been baptised. Before and immediately after the Revolution conferences were held bringing together all the pagan priests of the nation.

Persecution of paganism was intensified in the 1920s. Priests were repressed and every pagan prayer ceremony was the occasion for a police investigation. It became the custom to meet at night to pray. Only once, in 1949, did the Soviet authorities permit a national prayer meeting, dedicated to the victory over the Germans in 1945. Tens of thousands of believers gathered and the meeting lasted for more than a week. This event became engraved in the national memory as an important historical landmark.

What are the main features of Mari pagan belief today? Thanks to the involvement of the national cultural intelligentsia, Mari paganism is gradually beginning to experience an inevitable reformation. Work on the creation of a complete pagan 'scripture' based on mythology, prayers, incantations and rites has only just begun, but it is already replacing the oral 'tradition' which was all that previous generations of pagan priests had to rely on. In 1992 a book of prayers for various situations in everyday life was published; they were collected and edited by the ethnographer Nikandr 
Popov. This collection, which is now being actively used by today's literate pagan priests, is in fact the first religious text in the history of Mari paganism. Developments of this kind are continuing and it is possible that Mari paganism will follow a similar pattern to Chuvash paganism in its progress from polytheism to monotheism.

The Mari pagans claim that their faith is the purest of all faiths and has preserved spiritual truth better than any other. The supreme creator god Osh Kugu Yumo ('Big White God') is in the form of a man and is the chief god. Alongside him, and independent of him, are dozens of other gods, among the most respected of these being Mlade Avo ('Mother Earth'), Mer Yumo ('god of all living things') and Keche Ava Yumo ('Mother Sun'). Natural god-spirits inhabit sacred trees in the most sacred groves. The spirits of ancestors and of legendary heroes such as Chimbulat are also worshipped.

Since their revival in 1991 public prayer meetings have been held every year and the question of the ritual side of the cult has been raised. Most of the priests are trying to restore the ancient rites in their purest form, including the sacrifice of large numbers of animals. Horses, bulls, sheep and geese are slaughtered in sacred groves. These are considered to be the most worthy animals for sacrifice, but for the peasants the practice is ruinous, and it puts off townsfolk who never have to encounter blood in their daily lives. The minority of liberally minded pagan priests suggest that more consideration should be given to the mystical element of sacrifice and that they should all learn from the syncretic Mari sect of the end of last century, Kugu Sorta ('Big Candle'). Its founder T. Yakimanov considered himself neither pagan nor Christian. His aim was to harmonise the ritual side of paganism with modern cultural norms, and among other things he proposed substituting bread, honey and butter for the traditional blood sacrifice.

Nowadays the main followers of paganism, the plain-dwelling Mari, are as we noted earlier divided into 'pure' and 'dual' believers. 'Dual belief' must not be thought of as semi-Christian and semi-pagan. Dual believers are perfectly genuine pagans. They differ from the pure pagans in that they believe that the God of the neighbouring Russian nation is the same as their god Yumo, though with a different name. Practically every pagan cult practises a 'rite of harmony' with alien spirits, for whom special sacrifices are brought to certain places. Local Orthodox clergy testify to the fact that dual believers bring sacrificed birds to church and place them before the icon of 'the strong god with a weapon', as they refer to St George the Dragonslayer, and then run away, aware that the Orthodox do not approve of this practice. As a rule dual believers do baptise their children, but they never make confession or receive the sacrament. They say pagan prayers in front of icons and they celebrate Easter on Good Friday, evidently because while their religious consciousness accepts quite naturally the glorious death of the god-hero, there is no place for the concepts of atonement and resurrection, which belong to a different religious culture. To call them even semi-Christians, then, is impossible.

Despite their Finno-Ugrian origins the Mari have close affinities with the Tatars. Among dual believers and pure pagans the influence of Islam is very considerable. Many religious terms and concepts have been borrowed from Islam. The word kart is of Turkish origin and the pure Mari who live in Bashkiria call their priests mullahs. The concepts of 'paradise' and 'hell' also come from Islam ('uz'mak' and 'tamak'): they were unknown in early Mari paganism. Tatar influence is felt in the everyday life of society. If the Mordovian intelligentsia loves to emphasise its European origins and academic connections with Moscow and St Petersburg, then in Yoshkar-Ola 
it is considered particularly chic to graduate from Kazan' University.

Paganism may be getting its second wind today but the same cannot be said of Christianity. Christianisation as carried out by the Moscow government in the Volga region was greatly watered down by the time it reached deep into the Mari forests. There has been no consistent organised missionary activity among the Mari. Even at the turn of the century, when the other Volga nations were experiencing a national Orthodox enlightenment and translations of the scriptures were appearing, the Mari remained on the sidelines. The antipagan efforts of the tsarist government were basically limited to actions against mass public manifestations of pagnism. The Mari lands have never been made into a separate diocese but have always been attached to the diocese of Kazan'. In 1917 there were seven Orthodox churches in Tsarevokokshaisk (Yoshkar-Ola); in 1961 the last of them was closed through the combined efforts of Khrushchev's authorities and the local dean, who then defrocked himself. Yoshkar-Ola became the only capital city of an autonomous nation with not a single Orthodox church open for 30 years.

Today services are held in 35 Orthodox parishes in Mari El (compared with 126 parishes in Chuvashiya). They are scattered very unevenly around the country. Most of them are located around Yoshkar-Ola, which is inhabited chiefly by Russians who arrived there after the war to form the military-industrial complex; they are also to be found in the regions around Koz'modem'yansk inhabited by mountain-dwelling Mari. Services are held only in Slavonic. Only one Orthodox prayer book in a very small print-run has been published in the Mari language in recent years, and this was as a result of the personal efforts of a Chuvash priest who serves in a Chuvash village and has set up his own publishing concern to educate the local people by publishing religious literature in the Chuvash language. Of the 44 priests working in Mari El only a quarter are Mari. The church has no educational establishments or mass media outlets of its own, and it is extremely poor. The clergy in fact minister only to the Russians and a small number of mountain-dwelling Mari; they avoid the pagans, at once mocking them and being rather afraid of them.

This was the situation which greeted His Holiness the Patriarch of Moscow and All Russia Aleksi II when he arrived in Yoshkar-Ola on 24 July 1993 to inaugurate the hundredth diocesan see under the jurisdiction of the Russian Orthodox Church. The circumstances surrounding this inauguration of a new 'jubilee' diocese and the time and place chosen to consecrate its bishop (Ioann, formerly Ivan Ivanovich Timofeyev) deserve particular attention. The year 1991 was a turning-point in the contemporary history of the Mari nation. It was in that year that paganism was actively reborn, as was the closely linked sense of national identity. OshmariChimari was registered in 1991 and the first edition of Nikandr Popov's pagan service book came out. The republican parliament adopted a law concerned with 'the protection and rational use of the natural environment', article 55 of which states that henceforth 'religious cult zones' (i.e. sacred groves) come under the protection of the state and that 'no traditional Mari place of prayer is to be cut down or developed in any other way'. There are a large number of sacred groves in Mari El. One or more can be found in practically every village. They each have their different designations: some are 'ancestral', others belong to a certain village, others are specifically for women to use. There are also groves which are considered to be 'unclean' and where diseases and ailments can be 'cast off'.

After the registration of Oshmari-Chimari this law has in fact given paganism semi-official status. The government has reserved a 13-hectare plot of land on the edge of Yoshkar-Ola for the construction of the republic's main temple, which will 
be used for national prayer meetings. An educational centre is to be built which is to accommodate buildings for winter prayers, a national ethnographic museum and a hotel. The leaders of Oshmari-Chimari are asking the state to provide the money to build the temple and for its upkeep to be the responsibility of the Ministry of Culture.

It was also in 1991 that the first Mari president was elected, the mountain-dwelling Mari Vladislav Zotin. The inauguration ceremony took place in the national theatre and Zotin invited Bishop Anastasi of Kazan' to bless his presidency. However, the pagan lobby in the government intervened in the preparations for the inauguration and demanded that the unbaptised Zotin agree to a pagan blessing alongside the Orthodox one. So Bishop Anastasi found himself in the theatre auditorium standing near to the high priest of Oshmari-Chimari, that passionate champion of pure paganism Aleksandr Yuzykain. The first Mari president was thus blessed by two faiths, but he was not going to disguise his own Orthodox sympathies. A year later Zotin was publicly baptised into the Orthodox Church and had his flat consecrated. The next day this was the talk of Yoshkar-Ola, a town similar in size and manners to a provincial Russian town like Smolensk. Several months later Zotin asked Patriarch Aleksi to make Mari El a diocese in its own right, independent of Tatarstan. The initiative for this did not come from the Synod, then, but from a state official. At a meeting with President Zotin on 26 July 1993 the patriarch observed that "when the leaders of the Mari El republic requested us to create an independent diocese, the Holy Synod was in full agreement'! Vladislav Zotin insisted that the new bishop be named and consecrated in Yoshkar-Ola and not in Moscow as it often the case. The patriarch came to the Mari El capital with prelates from neighbouring dioceses: Archbishop Varnava of Cheboksary and Chuvashia, Archbishop Nikolai of Izhevsk and Udmurtia and Bishop Anastasi of Kazan' and Tatarstan. The three-day visit was packed with meetings with official personages: the president, the chairman of the Supreme Soviet and the secretary of state. Everything underlined the social and political significance of the visit, from receptions at the highest level to meetings between the patriarch and members of the local intelligentsia and business world. The patriarch appeared on local television with greetings to the whole Mari nation.

Protocol made no provision for a meeting between the patriarch and the pagan leader, and this caused distress in pagan circles. A senior high priest, Yakimov, dressed in his priestly robes, tried independently to meet the patriarch, but he was stopped by guards. However, the patriarch did not avoid the theme of paganism in his speeches. Speaking of the danger emanating from foreign religious expansion, he stressed that local Orthodox clergy did not want to fight paganism and that 'the traditional faiths and religious organisations of our country must live peacefully together and not oppose one another. Some Mari are Christians and some are pagans. The Russian population here is at root Orthodox, but the Orthodox will not inspire war and hatred towards other traditional creeds.' 2

Just how problematic was the feasibility of these two mutually exclusive religious confessions coexisting peacefully was shown by the fact that although Vladislav Zotin, the initiator of the visit with all its meetings and speeches, had to take pagan interests into account in the run-up to the next elections, he still intended, as before, to concentrate his political activities in the Christian part of the republic. 'I hope,' said Patriarch Aleksi, 'that from today, with the consecration of the new bishop, a new stage is beginning in the life of this diocese. We are convinced of this by the support of the republic's president who has been working hard for its creation. ${ }^{3}$ At all events, the creation of an Orthodox diocese in a pagan region was undoubtedly a call to his political supporters. 
Our analysis of the religious and political situation in Mari El leads us to recognise the strength of paganism, which will potentially affect the political situation not only within the republic but in the whole of Russia. In order to predict the nature of this effect, two questions need to be asked. With which religion will the national consciousness ultimately identify itself? Which religion will the authorities represent in the future?

It is relatively easy to answer the first question. Orthodox Christianity will succeed in taking root among the Mari only if it takes into account their national and cultural peculiarities and translates the liturgy into the Mari language without delay. To accomplish this the genuine support of the bishop will be necessary, as well as the time and the money to produce translations of quality which convey the profundity of Orthodox theology. Priests, preferably of Mari origin, must be trained. However, even with all the will and money in the world this could take years, years in which paganism, with support from both government and society, could well become rooted in the culture and literature of the nation.

It is impossible to answer the second question at the present time, but we can look at both possible answers. If Zotin and his supporters manage to stay in power then with a little skillful manoeuvring Moscow's influence will be strengthened in Mari $\mathrm{El}$, placing limitations on the strong sense of national identity among sections of Mari society but guaranteeing relative political stability. However, it is entirely possible that the supporters of pagan self-determination will topple the 'Christian' authorities at the next elections. If this happens then the predominantly pagan nation of Mari El will become the only nation-state in Europe in which paganism is the recognised state religion. It also means that Mari El, already a centre of attraction for pagans from other autonomous republics such as Mordovia and Udmurtia, would become a spiritual core around which the pagans of various different ethnic origins who live in the Volga region would gather. A common faith together with a series of political circumstances could thus thus lead to the creation of a separatist-minded union of the Volga nations more monolithic than the association of the mountain nations of the Caucasus. The ancestral faith would be its unifying ideological basis. In this case the 'pagan factor' would be heard at full volume and demand a response from the rest of Russia.

\section{Notes and References}

1 Offitsial'naya khronika, Moscow Patriarchate, no. 7/8, 1993.

2 op. cit.

3 op. cit.

(Translated from the Russian by Emma Watkins and Philip Walters) 